\title{
Financial Sophistication, Personality and Stock Market Participation: Theory and Evidence
}

\section{Muhammad Akhtar*, Faqir Muhammad ${ }^{* *}$ and Muhammad Ayub Siddiqui ${ }^{* * *}$}

\begin{abstract}
In this empirical study, the authors examined the extent to which financial sophistication and personality effects stock market participation. Using archival research methodology, our hypothesis has been tested on a random sample of 451 stock market participants. Moderation has been tested through Andrew Hayes process. Extroversion and openness to experience positively impact stock market participation, while consciousness, agreeableness, and neuroticism have a negative impact. Financial literacy, trading experience and gender are the likely paths by which personality impacts stock market participation. Financial literacy can modify the relationship between some basic personality traits and stock market participation. It shows that behavior finance is not completely predetermined by one's DNA and also identifies which traits are less influenced by financial literacy. Perhaps this implies that these traits are more predetermined by one's innate characteristics.

This study provides an interdisciplinary contribution by extending Big Five taxonomy as a viable approach for stock market participation. Future research may investigate the impact of family resources, investment exposure, and parent's financial literacy, which were beyond the scope of the current study. The theoretical and practical implications of the study with respect to stock market participation are discussed.
\end{abstract}

Keywords: Financial sophistication; big five personality traits; behavioral finance, stock market participation.

JEL Classification: G11, G22, G23, A22, C01

\footnotetext{
* Assistant Professor, FAST School of Management, National University of Computer \& Emerging Sciences, Islamabad. Email: muhammad.akhtar@nu.edu.pk

** Professor, Air University School of Management (AUSOM), Faculty of Administrative Sciences, Air University, Islamabad. Email: aioufsd@yahoo.com

*** Professor, FAST School of Management, National University of Computer \& Emerging Sciences, Islamabad. Email: ayub.siddiqui@nu.edu.pk
} 


\section{Introduction}

Behavioral finance has sparked many debates in the area of stock market participation and researchers are continuously trying to find the drivers of stock market participation. The precise mechanism through which financial sophistication and personality affects stock market participation remains poorly understood. Although many researchers have examined stock market participation (Van Rooij, Lusardi \& Alessie 2011; Balloch, Nicolae \& Philip, 2014; Bodnaruk \& Simonov, 2015; Hilgert, Hogarth \& Beverly 2003; Jappelli \& Padula, 2013; Abreu \& Mendes, 2010; Calcagno \& Monticone, 2015; Gaudecker \& Von, 2015) there remains a lack of understanding between financial sophistication, personality and stock market participation. Personality may drive individuals towards stock market participation, because it has significant impact on the choices individuals make (Cobb-Clark and Schurer, 2012). For example the Big Five has association with financial and economical choices (Belcher, 2010), with risk aversion (Filbeck, Hatfield \& Horvath, 2005), job performance (Zeigler-Hill, Besser, Vrabel \& Noser, 2015) and household finances (Brown \& Taylor, 2014). At the same time, the current study illustrate that financial literacy, trading experience and gender are the likely paths by which personality affects stock market participation.

Behavioral intentions in investment management have been largely explored by researchers (Mayfield, Perdue \& Wooten, 2008), such as trust on financial markets (Guiso, Sapienza \& Zingales, 2008), ability to understand investments (Jappelli \& Padula, 2011), financial literacy (Cardak \& Wilkins, 2009; Van Rooij et al., 2011), financial superiority (Christelis, Georgarakos \& Haliassos, 2011) and investment behavior of individuals (Bodnaruk \& Simonov, 2015; Gaudecker \& Von, 2015). Financial literacy gained attention due to multifarious financial products in the market (Wang, 2009). Understanding the barriers to financial choice, defining and measuring impacts of financial literacy is vital (Huston, 2010). There is also a paucity of research in Pakistan with respect to personality, financial sophistication and stock market participation. Financial competence significantly affects performance of stock market participants (Bateman et al., 2012). Individuals with extensive financial knowledge are able to predict future financial crises and expressing uncertainty.

The majority of studies in the domain have been conducted in developed countries like the Netherlands and the United States. Being an important Asian state, multinationals are investing in Pakistan (Abbas, Raja, Darr \& Bouckenooghe, 2012). Therefore, to provide researchers and 
practitioners with confidence, there is a need to test the theories developed in Western settings, to check their generalisability in Asian settings (Tsui, Nifadkar \& Ou, 2007). The next section of the study discusses literature review related to personality, financial sophistication and stock market participation. The methodology section presents information regarding data analysis techniques, estimation of results and details of Andrew Hayes (2012) process. The final section concludes with finding and implications.

\section{Literature Review}

\subsection{Extroversion and Stock Market Participation}

"Extroversion concerns the extent to which individuals are gregarious, assertive, and sociable versus reserved, timid, and quiet (Salgado, 1997, p.30)". "Extroversion includes characteristics such as excitability, sociability, talkativeness, assertiveness and high amounts of emotional expressiveness" (Barrick \& Mount, 1991, p. 44). Extroverts have great need of social status, economic reward, authority and acknowledgment (Costa \& McCrae, 1988, p. 712). Having the energy and optimism required to initiate and persist in coping efforts, like primary control management (providing solution and support for problems) and secondary control management (showing more positive or realistic way) (Lengua, Sandler, West, Wolchik \& Curran, 1999), investors with extroverted personality show more eagerness and stimulation towards most of the portfolios (Mitteness, Sudek \& Cardon, 2012). They prefer investment opportunities that balance out their alternatives. Even in the work place their satisfaction level as compare to neurotics enhance with the passage of time (Scollon \& Diener, 2006). They also have more propensity to taking credit card debt than those with high conscientiousness (Brown \& Taylor, 2014). This means that extroverts may be more eager to take risks using their tendency towards debt as an indicator of risk-taking tendency (Brown, Garino \& Taylor, 2013). They feel happy to be social therefore; they interact with a diverse range of people (Zhao \& Seibert, 2006). This establishes that individuals with more social contacts are risk lovers (Wasiuzzaman \& Edalat, 2016). They are innovative and mainly achieve superior portfolio performance. Extroversion enhances the relationship between perceived passion and evaluation of funding potentials. Therefore, investors with the optimistic approach are more likely to make investments in stock (Olsen, 2012; Liu \& Jiang, 2012). But this is not consistent as it may vary with variation in economic conditions (Liu \& Jiang, 2012). Therefore, such people typically display a lot of 
enthusiasm and excitement in their lives due to their extroverted personalities. Consequently, this study proposes the following hypotheses:

Hypothesis 1: Investors with extrovert personality shows more eagerness and motivation towards stock market participation.

\subsection{Openness to Experience and Stock Market Participation}

Openness to experience includes "individuals who are creative, curious, and cultured versus practical with narrow interests (Salgado, 1997, p. 30)". "Openness is reflected in a strong intellectual curiosity and a preference for novelty and variety" (Komarraju, Karau, Schmeck \& Avdic, 2011, p. 472). These individual show great elements of creativity, innovation, and novelty. They play with new ideas and prefer to take risks instead of working in traditional ways. Openness to experience personality possesses the element of creativity which leads to risk taking (George \& Zhou, 2007). Like extroversion, those with openness to experience also possess entrepreneurial development skills (Caliendo, Fossen \& Kritikos, 2011). Investors with high risk-taking tendencies and a high degree of openness to experience pursue a greater portfolio risk (Durand, Newby \& Sanghani, 2008). Furthermore, personalities with high risk-taking tendencies and a high degree of openness to experience also enhance the trade manners of investors (Durand et al., 2008). These personalities have a direct relationship with hindsight and overconfidence biases relating to investments (Sadi, Rostami, Gholipour, and Gholipour, 2011). In the same vein, several studies (see for example Dohmen, Falk, Huffman, \& Sunde, 2010; Borghans, Golsteyn, Heckman \& Meijers, 2009) found a negative relationship between openness to experience and risk aversion. Mitteness et al. (2012) however, found that investors who are older, more intuitive, with a high open personality have the tendency to invest more. Similarly, Lauriola \& Levin (2001) articulates that individuals with openness to experience are eager to take risks. Mayfield et al. (2008) found a positive correlation between risk and openness to experience. Individuals with openness to experience express a positive attitude towards online shopping, which represents their risk-taking tendency (Mendonca, 2016). Therefore, this study proposed that:

Hypothesis 2: The individuals having openness to experience trait show more zeal and inspiration towards stock market participation. 


\subsection{Neuroticism and Stock Market Participation}

"Neuroticism concerns the degree to which the individual is insecure, anxious, depressed, and emotional versus calm self-confident and cool " (Salgado, 1997, p. 30-). "Neuroticism refers to the degree of neuroticism, impulse control, and anxiety" (Komarraju et al., 2011, p. 472-). Neurotic personalities do not encourage social relationships and are reluctant to get engage in a situation in which control is needed (Judge, Locke \& Durham, 1998). In financial decision-making, behavior influences procedure, but the relationship between financial decision-making and genetics is poorly understood (Kuhnen, Samanez-Larkin \& Knutson, 2011). It has emerged that mental and emotional stimuli have a great impact on investment decisions (Virlics, 2013). They further document that psychological evidence shows that neurotic persons avoid risky and complex financial choices (Virlics, 2013). Individuals with high neuroticism are risk-averse because they are depressed, insecure and anxious. This prevents them from becoming engaged in activities in which uncertainty exists. Therefore, the individuals who score high on neuroticism have a low tendency for risk-taking. The investors with a high level of neuroticism experience much more regret than those having lower neuroticism when facing poor investment decisions (Xiao, Wang \& Liu, 2009). The findings of Lauriola and Levin (2001) demonstrate that individuals with high neuroticism have less tendency towards risk-taking. Therefore on the basis of the above arguments, this study hypothesizes that:

Hypothesis 3: Individuals with neurotic personalities may avoid risky and complex financial choices and participate less in stock market.

\subsection{Conscientiousness and Stock Market Participation}

"Conscientiousness measures the extent to which individuals are hardworking, organized, dependable, persevering versus lazy, disorganized, and unreliable" (Salgado, 1997, p. 30). "Conscientiousness is exemplified by being disciplined, organized, and achievement-oriented" (Komarraju et al., 2011, p. xx). Conscientious people are greatly concerned with the completion of a task (Stewart, 1996 p. 620). Instead of doing things with new patterns they prefer to do things in an organized way because doing things in new way requires innovation and creativity which ultimately leads to risk. The individual who has more concern about sensing or judging the things they have a lower tendency towards risk ( $\mathrm{Li}$ \& Liu, 2008). However, analysis shows that trading and disposition effects 
are associated with conscientiousness (Durand, Newby, Tant \& Trepongkaruna, 2013). Highly conscientious people do participate in stock markets. The influence of personality traits has a significant effect on investment management (Nga \& Ken Yien, 2013). Individuals with high conscientiousness were found to manage money very well (Donnelly, Iyer \& Howell, 2012). Because of proper money management, they have a low tendency towards debt and impulsive buying (Donnelly et al., 2012). With time, they review their exchange relationships to escape from any unpleasant situations due to risk aversion (Gosling, Rentfrow \& Swann, 2003). Brown et al. (2013) depicts that the risk averse household has a negative correlation with debt level, and they are concerned about the future. Because conscientious individuals are risk averse, and creativity involves inherent risky, conscientiousness is inversely correlated with creativity (George \& Zhou, 2001). On the basis of the above arguments, it is hypothesizing that:

Hypothesis 4: Individuals with the conscientiousness personality trait may not participate in stock markets

\subsection{Agreeableness and Stock Market Participation}

"Agreeableness includes attributes such as trust, altruism, kindness, affection, and other pro-social behaviors" (Barrick \& Mount, 1991, p. 44). Agreeableness can also be defined as "being helpful, cooperative, and sympathetic towards others" (Komarraju et al., 2011, p. 472 p. xx). Individuals with agreeableness personality trait have a great tendency towards social work. They help people without benefit to themselves so they do not have concern with risk and return. Agreeable individuals have a greater tendency towards cooperation and will prefer not to engage in activity which requires a great deal of risk. The big five personality traits influence risk-taking behavior (Bashir, Azam, Nazish, Butt, Javed \& Tanvir, 2013). Similarly, Durand et al. (2006) found that agreeableness is inversely correlated with investment in stock. Zuckerman and Kuhlman (2000) indicated that agreeableness is inversely correlated with risk-taking. Several studies showed a positive correlation between agreeableness and risk aversion. Brown and Taylor (2014) purports that individuals with the agreeableness trait are less likely to make an investment in stocks as compare to others because they are risk averse. Zuckerman and Kuhlman (2000) indicate that agreeableness is inversely correlated with risk-taking. Fenton-O'Creevy, Soane and Willman (2001) found that those with agreeableness have a lower tendency towards risk- 
taking as compare to other personality traits. So, on the basis of above arguments, the study hypothesized that:

Hypothesis 5: Agreeableness is negatively correlated with stock market participation.

\subsection{Financial Literacy and Stock Market Participation}

Financial literacy is "the ability to make informed judgments and take effective decisions regarding the use and management of money" (Schagen \& Lines, 1996, p.37). Lack of financial knowledge has an adverse impact on investors (Yoong, 2010). Investors with financial knowledge have suffered minimally from the recent financial crises due to their financial literacy (Bucher-Koenen \& Ziegelmeyer, 2011). Individual risktaking tendency depends upon knowledge of investment, wealth and gender (Dulebohn, 2002). Investment diversification and financial literacy are positively associated (Abreu \& Mendes, 2010). Individuals with poor financial literacy lack confidence (Disney \& Gathergood, 2013).

Therefore, association exists between financial knowledge and financial decisions (Jappelli \& Padula, 2011). People equipped with financial information demonstrate more risky behavior than the masses who demonstrate avoidance behavior towards credit card usage (Borden, Lee, Serido \& Collins, 2008). In the absence of financial knowledge, investors are vulnerable to forecast earlier period growth before making an investment (Muller \& Weber, 2010). Individual behavior regarding investment in the stock market is quite different for every individual. Individuals avoid negative information and do not like to own diversified stocks (Barber \& Odean, 2011). Therefore, level of education is a determinant of risk-taking; educated investors take more risk compare to less educated (Riley \& Chow, 1992). More specifically, an individual's risktaking tendency depends on their financial knowledge, such as the rules of investment, wealth and gender (Dulebohn, 2002). Financial literacy diminishes the risk-averse tendency of investors, and provides a variety of ways to deals with risk (Jung, 2015). Low financial knowledge leads to lower confidence in making financial dealings (Disney \& Gathergood, 2013). The financial knowledge of investors is positively correlated with investment diversification (Abreu \& Mendes, 2010). A household with trust and literacy have more chances of investments (Balloch et al., 2014). Individuals with overconfidence and over-optimism are significantly associated with risk-taking behavior (Breuer, Riesener \& Salzmann, 2014). The overconfidence personality bias stimulates investors to invest in risky 
assets (Dittrich, Guth \& Maciejovsky, 2005). Overconfident individuals are more optimistic than rational investors (Kliger \& Levy, 2010). The extrovert spends less time on judging risk ( $\mathrm{Li} \& \mathrm{Liu}, 2008)$. Therefore, the study proposes that:

Hypothesis 6: There is a moderating impact of financial literacy on the relationship between personality and stock market participation.

\section{Research Methodology}

\subsection{Collection of Data}

To capture a representative sample the data were collected from the Pakistan stock exchange and from brokerage houses working in different cities of Pakistan through personal and professional links. Access to stock market participants was also made possible through the owners of brokerage houses. Of the 600 distributed questionnaires, we received 451 completed questionnaires, providing a response rate of 75 percent.

\subsection{Measures for Extroversion}

Extroversion was measured using a 5-point Likert scale against items such as "I see myself as someone who is talkative". The Likert scale ranged from 1 (strongly disagree) to 5 (strongly agree). Confirmatory Factor Analysis (CFA) was used to measure of the construct consistency. CFA results revealed GFI $=0.92$ and $\mathrm{RMSEA}=0.05$. To create an overall measure of extroversion, the study averaged scores on all 8 items relating to extroversion, such that a higher score represents higher extroversion and a lower score represents lower extroversion. Cronbach's alpha for extroversion of was 0.84, which meets the acceptable standard for reliability Nunnally \& Bernstein, 1994.

\subsection{Measures for Openness to Experience}

Openness to Experience was measured using a 5-point Likert scale against items such as "Is original, comes up with new ideas". The Likert scale ranged from 1 (strongly disagree) to 5 (strongly agree). CFA was used to measure of the construct consistency. CFA results revealed GFI $=0.95$ and RMSEA $=0.05$. To create an overall measure of openness to experience, the study averaged scores on all 10 items relating to openness to experience, such that a higher score represents higher openness to 
experience and a lower score represents lower openness to experience. Cronbach's alpha for openness to experience of was 0.83 , which meets the acceptable standard for reliability Nunnally \& Bernstein, 1994.

\subsection{Measures for Neuroticism}

Neuroticism was measured using a 5-point Likert scale against items such as "I see myself as someone who can be tense". The Likert scale ranged from 1 (strongly disagree) to 5 (strongly agree). CFA was used to measure of the construct consistency. CFA results revealed GFI $=0.93$ and RMSEA $=0.06$. To create an overall measure of neuroticism, the study averaged scores on all 8 items relating to neuroticism, such that a higher score represents higher neuroticism and a lower score represents lower neuroticism. Cronbach's alpha for neuroticism of was 0.77, which meets the acceptable standard for reliability Nunnally \& Bernstein, 1994.

\subsection{Measures for Conscientiousness}

Conscientiousness was measured using a 5-point Likert scale against items such as "I see myself as someone who does a thorough job". The Likert scale ranged from 1 (strongly disagree) to 5 (strongly agree). CFA was used to measure of the construct consistency. CFA results revealed GFI $=0.92$ and RMSEA $=0.05$. To create an overall measure of conscientiousness, the study averaged scores on all 9 items relating to conscientiousness, such that a higher score represents higher conscientiousness and a lower score represents lower conscientiousness. Cronbach's alpha for neuroticism of was 0.74 , which meets the acceptable standard for reliability Nunnally \& Bernstein, 1994.

\subsection{Measures for Agreeableness}

Agreeableness was measured using a 5-point Likert scale against items such as "I see myself as someone who is helpful and unselfish with other". The Likert scale ranged from 1 (strongly disagree) to 5 (strongly agree). CFA was used to measure of the construct consistency. CFA results revealed GFI $=0.91$ and RMSEA $=0.06$. To create an overall measure of agreeableness, the study averaged scores on all 9 items relating to agreeableness, such that a higher score represents higher agreeableness and a lower score represents lower agreeableness. Cronbach's alpha for neuroticism of was 0.72 , which meets the acceptable standard for reliability Nunnally \& Bernstein, 1994. 


\subsection{Measures for Stock Market Participation}

"Stock market participation is defined as owning individual stocks and/or mutual funds" (Van Rooij et al., 2011, p. 450). The individual was considered a stock market participant if they were trading in stock, mutual funds or debt instruments. Stock market participation was assessed using 5 point Likert scale, which ranged from 1 (never participated) to 5 (very regularly participated), such that a higher score represents higher participation and a lower score represents lower participation.

\subsection{Measure for Financial Sophistication}

Financial literacy has been measured using The Big Three, a scale developed by Lusardi and Mitchell (2008; 2011). It contains questions regarding numeracy, interest compounding, inflation and risk diversification. The Big Three questions includes simple questions (Olivia, Mitchell \& Lusardi, 2015) which differentiate between degrees of financial sophistication (Olivia et al., 2015), e.g. "Buying a single company stock usually provides a safer return than a stock mutual fund" (Lusardi \& Mitchell, 2014). These questions are derived from different surveys such as the Health and Retirement Survey (HRS), Health and Retirement Study, National Longitude Survey of Youth and US National Financial Capability Study (Lusardi, 2008; Lusardi \& Mitchell, 2011b; Lusardi \& Mitchell, 2011; 2014).

\subsection{Model Summary}

Statistical Model to Examine the Impact of Extroversion on Stock Market Participation with Moderating Effect of Financial Literacy, Trading Experience and Gender

$$
\begin{aligned}
S M P= & \beta_{0}+\beta_{1}(E x t)+\varepsilon S M P \\
S M P= & \beta_{0}+\beta_{1}(E x t)+\beta_{2}(F L)+\beta_{3}(T E)+\beta_{4}(G)+\beta_{5}(E x t)(F L)+\beta_{6}(E x t)(T E) \\
& +\beta_{7}(E x t)(G)+\varepsilon_{S M P}
\end{aligned}
$$

Statistical Models to Examine the Impact of Openness to Experience on Stock Market with Moderating Effect of Financial Literacy, Trading Experience and Gender Participation

$$
\begin{aligned}
S M P= & \beta_{0}+\beta_{1}(\text { Open })+\varepsilon_{S M P} \\
S M P= & \beta_{0}+\beta_{1}(\text { Open })+\beta_{2}(F L)+\beta_{3}(T E)+\beta_{4}(G)+\beta_{5}(\text { Open })(F L)+ \\
& \beta_{6}(\text { Open })(T E)+\beta_{7}(\text { Open })(G)+\varepsilon_{S M P}
\end{aligned}
$$


Statistical Model to Examine the Impact of Neuroticism on Stock Market Participation with Moderating Effect of Financial Literacy, Trading Experience and Gender

$$
\begin{aligned}
S M P= & \beta_{0}+\beta_{1}(\text { Neur })+\varepsilon_{S M P} \\
S M P= & \beta_{0}+\beta_{1}(\text { Neur })+\beta_{2}(F L)+\beta_{3}(T E)+\beta_{4}(G)+\beta_{5}(\text { Neur })(F L)+ \\
& \beta_{6}(\text { Neur })(T E)+\beta_{7}(\text { Neur })(G)+\varepsilon_{S M P}
\end{aligned}
$$

Statistical Model to Examine the Impact of Conscientiousness on Stock Market Participation with Moderating Effect of Financial Literacy, Trading Experience and Gender

$$
\begin{aligned}
& S M P=\beta_{0}+\beta_{1}(\text { Cons })+\varepsilon_{S M P} \\
& S M P=\beta_{0}+\beta_{1}(\text { Cons })+\beta_{2}(F L)+\beta_{3}(T E)+\beta_{4}(G)+\beta_{5}(\text { Cons })(F L)+ \\
& \beta_{6}(\text { Cons })(T E)+\beta_{7}(\text { Con })(G)+\varepsilon_{S M P}
\end{aligned}
$$

Statistical Model to Examine the Impact of Agreeableness on Stock Market Participation with Moderating Effect of Financial Literacy, Trading Experience and Gender

$$
\begin{aligned}
S M P= & \beta_{0}+\beta_{1}(\text { Agree })+\varepsilon_{S M P} \\
S M P= & \beta_{0}+\beta_{1}(\text { Agree })+\beta_{2}(F L)+\beta_{3}(T E)+\beta_{4}(G)+\beta_{5}(\text { Agree })(F L)+ \\
& \beta_{6}(\text { Agree })(T E)+\beta_{7}(\text { Agree })(G)+\varepsilon_{S M P}
\end{aligned}
$$

Where:

$\mathrm{SMP}=$ Stock market participation, Ext $=$ Extroversion, Open $=$ Openness to experience, Neur = Neuroticism, Cons = Conscientiousness, Agree $=$ Agreeableness, $\mathrm{FL}=$ Financial Literacy, $\mathrm{TE}=$ Trading Experience, and $\mathrm{G}=$ Gender

\section{Results}

Descriptive results are presented in tables given below which shows descriptive statistics of the variables. 
Table 1: Descriptive Statistics of the variables

\begin{tabular}{lccccrr}
\hline & $\mathbf{N}$ & Range & Min & Max & Mean & \multicolumn{1}{c}{ SD } \\
\hline SMP & 451 & 4.00 & 1.00 & 5.00 & 3.5211 & 1.52064 \\
Num & 451 & 1.00 & .00 & 1.00 & .7894 & .40822 \\
Int.C & 451 & 1.00 & .00 & 1.00 & .7871 & .40978 \\
Inflat. & 451 & 1.00 & .00 & 1.00 & .7871 & .40978 \\
TVM. & 451 & 1.00 & .00 & 1.00 & .7849 & .41133 \\
M.illu. & 451 & 1.00 & .00 & 1.00 & .7871 & .40978 \\
Risk. & 451 & 1.00 & .00 & 1.00 & .7849 & .41133 \\
Port. & 451 & 1.00 & .00 & 1.00 & .7783 & .41587 \\
Ext. & 451 & 4.00 & 1.00 & 5.00 & 3.7470 & 1.01178 \\
Agree. & 451 & 4.00 & 1.00 & 5.00 & 3.5556 & .62710 \\
Cons. & 451 & 4.00 & 1.00 & 5.00 & 3.3954 & .68951 \\
Neur. & 451 & 4.00 & 1.00 & 5.00 & 3.0989 & .83313 \\
Open. & 451 & 4.00 & 1.00 & 5.00 & 3.5430 & .74049 \\
Age & 451 & 4.00 & 1.00 & 5.00 & 1.9313 & .84442 \\
TE & 451 & 5.00 & .00 & 5.00 & 3.1463 & 1.48200 \\
\hline
\end{tabular}

Note: $\mathrm{N}=451 ; \mathrm{SMP}=$ Stock Market Participation, Num = Numeracy, Int.C = Interest Compounding, Inflat = Inflation, TVM = Time Value of Money, M.Illu = Money Illusion, Risk $=$ Risk Diversification, Port $=$ Portfolio management, Ext $=$ Extroversion, Agree $=$ Agreeableness, Cons. $=$ Conscientiousness, Neur. $=$ Neuroticism, Open. $=$ Openness to Experience, $\mathrm{TE}=$ Trading Experience, $\mathrm{FL}=$ Financial Literacy,

Table 2: Variables, No. of Item and Cronbach Alpha Reliabilities

\begin{tabular}{llcc}
\hline S. No. & Name of Variable & $\begin{array}{c}\text { No. of Items to Measure } \\
\text { Construct }\end{array}$ & $\begin{array}{c}\text { Cronbach Alpha } \\
\text { Reliabilities }\end{array}$ \\
\hline 1 & Extroversion & 8 & 0.840 \\
2 & Openness to experience & 10 & 0.837 \\
3 & Neuroticism & 8 & 0.778 \\
4 & Conscientiousness & 9 & 0.746 \\
5 & Agreeableness & 9 & 0.725 \\
\end{tabular}

Table 3: Variables, Coefficients, Se, $T$ and P values by Andrew F. Hayes Process

\begin{tabular}{lcccccc}
\hline Variables & $\mathbf{B}$ & SE $\boldsymbol{\beta}$ & $\mathbf{t}$ value & P value & LLCI & ULCI \\
Extroversion & 0.1996 & .0737 & 2.7063 & .0071 & .0547 & .3445 \\
Openness to Experience & 0.1852 & .0705 & 2.6267 & .0089 & .0466 & .3237 \\
Neuroticism & -0.0321 & .0575 & -.5590 & .5764 & -.1451 & -.0808 \\
Consciousness & -0.1799 & .0730 & -2.4649 & .0141 & -.3233 & -.0365 \\
Agreeableness & -0.4404 & .0850 & -5.1829 & .0000 & -.6074 & -.2743 \\
\hline
\end{tabular}




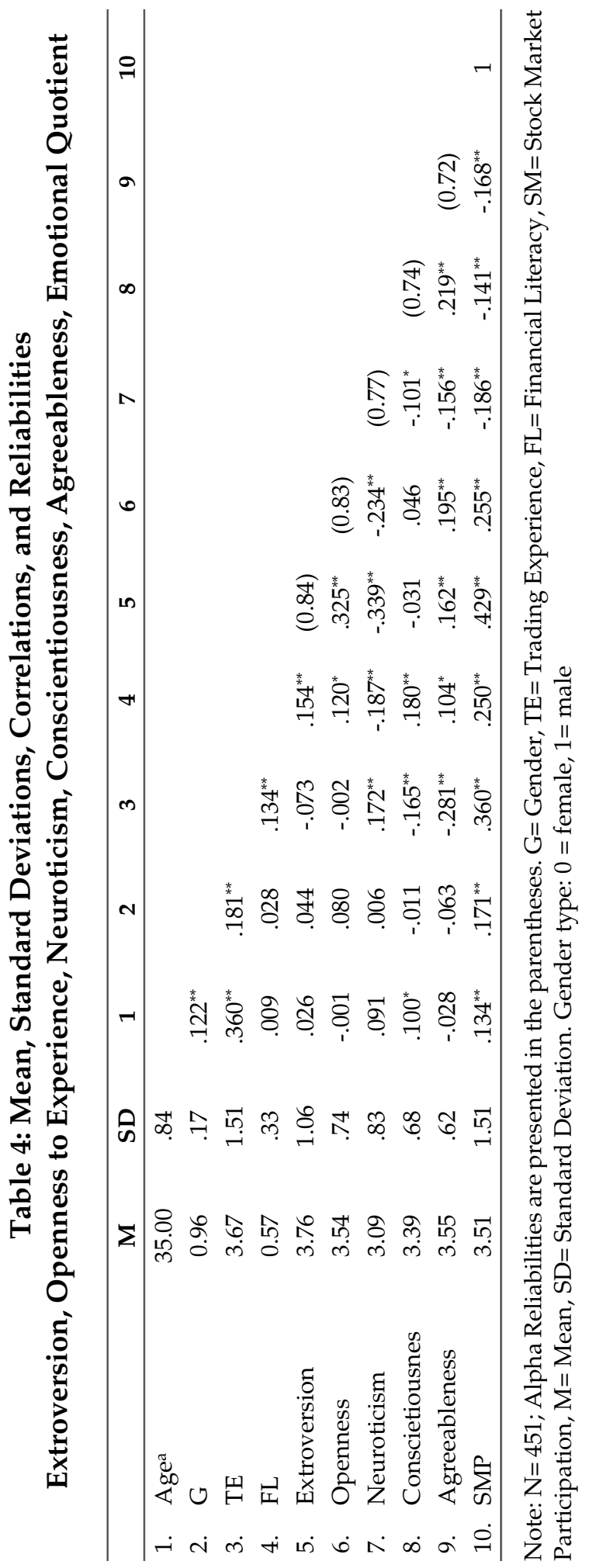


Table 5: Main Effects and Moderated Regression Analyses

\begin{tabular}{|c|c|c|c|}
\hline & & \multicolumn{2}{|c|}{ Stock Market Participation } \\
\hline & & B & $\Delta \mathbf{R}^{2}$ \\
\hline \multirow[t]{4}{*}{ Step1 } & (Constant) & 1.344 & \\
\hline & Age & -.004 & \\
\hline & G & .955 & \\
\hline & $\mathrm{TE}$ & $.342^{* * *}$ & $0.141^{* * *}$ \\
\hline \multirow[t]{9}{*}{ Step 2.} & Age & .015 & \\
\hline & G & .570 & \\
\hline & $\mathrm{TE}$ & $.358^{* * *}$ & \\
\hline & Ext & $.54^{* * *}$ & \\
\hline & Open & $.23^{* * *}$ & \\
\hline & Neur & $-.146^{*}$ & \\
\hline & Cons & $-.189^{*}$ & \\
\hline & Agree & $-.412^{* * *}$ & \\
\hline & FL & $1.17^{* * *}$ & $0.332^{* * *}$ \\
\hline \multirow[t]{5}{*}{ Step 3.} & ExtxFL & $0.073^{*}$ & \\
\hline & OpenxFL & $0.078^{*}$ & \\
\hline & NeurxFL & 0.153 & \\
\hline & ConsxFL & 0.048 & \\
\hline & AgreexFL & 0.035 & $0.002^{* * *}$ \\
\hline
\end{tabular}

Note: $\mathrm{N}=451 ; \mathrm{G}=\mathrm{Gender}, \mathrm{TE}=$ Trading Experience, Ext=Extroversion, Open=Openness to experience, Neur=Neuroticism, Cons $=$ Consciousness, Agree=Agreeableness, $\mathrm{FL}=$ Financial Literacy, $\mathrm{SM}=$ Stock Market Participation.

The results of table 3 showed that the correlation between agreeableness and stock market participation was negative and significant $(\beta=-0.168, P<0.05)$. Extraversion and openness to experience were positively and significantly correlated with stock market participation $(\beta=$ $0.429, P<0.05)$ and for openness to experience $(\beta=0.255, P<0.05)$. Conscientiousness and neuroticism were negatively correlated with stock market participation $(\beta=-0.141, P<0.05)$ and for neuroticism $(\beta=-0.186$, $P<0.05)$. Correlation between financial literacy and stock market participation was positive and significant $(\beta=0.250, P<0.05)$.

The regression result shows $\beta$ coefficients, $P$ values and $R$ square. $R$ square is 0.298 and probability value is $P<0.001$ which shows the change explained by extroversion in dependent variable. The sign of the coefficient of extroversion was positive with a value of $0.570, t$ value is 8.943 and $p$ value is $P<0.001$ which means that extroversion has positive and 
significant relationship at 5\% significance level with stock market participation. Therefore investors with extrovert personality are more eager and willing to participate in stock market. The direct regression between openness to experience and stock market participation showed, $\mathrm{R}$ square is $(0.298)$ and probability value is $(P=0.000)$ which show the change explained by the model in dependent variable. The coefficient sign of openness to experience is positive and the value is (0.339), $t$ value is (3.834) and $\mathrm{P}$ value is $(P=0.000)$ which means that openness to experience has positive and significant relationship with stock market participation. Neuroticism and stock market participation showed the following results. $\mathrm{R}$ square is (0.298) and probability value is $(0.000)$ which show the change explained by the model. Coefficient neuroticism was negative and the value is $(-0.109), t$ value is $(-1.386)$ and $p$ value is (0.166) which means that neuroticism has negative and significant relationship with stock market participation. Regression results proved the third hypothesis of the study that the individuals with neurotic personality avoid risky and complex financial choices does not participate in stock markets. The regression table shows the direct regression between conscientiousness and stock market participation. $R$ square is (0.298) and probability value is (0.000) which show the change explained by the model. Coefficient of conscientiousness has value (-0.176), $t$ value is (-1.935) and $p$ value is (0.054) which means that conscientiousness has negative and significant relationship with stock market participation. The result proves the fourth hypothesis of the study that the individuals with conscientious personality have fewer chances of their participation in stock markets. Regression results between agreeableness and stock market participation showed R square is (0.298) and probability value is $(0.000)$ which show the change explained by the model. Coefficient of agreeableness was $(-0.603), t$ value is $(-6.136)$ and $p$ value is (0.000) which means that agreeableness has negative and significant relationship at $5 \%$ level of significance with stock market participation. Results proved fifth hypothesis of the study that the individuals' high in agreeableness, have less chances of stock market participation.

\section{Conclusion}

Extroversion and openness to experience have significant and positive impact on stock market participation, in line with Nicholson, Soane, Creevy and Willman (2005). Investors who score high on openness have the tendency to invest (Mitteness et al., 2012). "Openness is reflected in a strong intellectual curiosity and a preference for novelty and variety" (Komarraju et al., 2011, p. 472). This novelty and variety 
induce individuals towards stock market participation. Neuroticism and conscientiousness have a negative impact on stock market participation. Neurotics avoid risky and complex financial choices Virlics (2013) and possess low tendency towards risk taking (Lauriola \& Levin, 2001). They experience regret in the face of poor investment decisions (Xiao, Wang \& Liu, 2009). Agreeableness also has a negative impact on stock market participation in line with the portfolio theory of Markowitz, (1952) which articulates that risk taking is associated with risk attitude (Zuckerman \& Kuhlman, 2000). Financial literacy moderated the relationship between extroversion; openness to experience and stock market participation but does not moderate in the case of neuroticism, conscientiousness and agreeableness. The findings protect investors from scams and frauds and will boost confidence towards stock market participation. Future research should investigate the impact of Family Resource Management Theory (FRMT), along with city wise analysis of stock market participants. However, family background, resources, investment exposure and family financial literacy were beyond the scope of the current study. 


\section{References}

Abbas, M., Raja, U., Darr, W., \& Bouckenooghe, D. (2012). Combined effects of perceived politics and psychological capital on job satisfaction, turnover intentions, and performance. Journal of Management. 40(7), 1813-1830.

Abreu, M. \& Mendes, V. (2010). Financial literacy and portfolio diversification. Quantitative finance, 10(5), 515-528.

Balloch, A., Nicolae, A., \& Philip, D. (2014). Stock market literacy, trust, and participation. Review of Finance, 19(5), 1925-1963.

Barber, B. M., \& Odean, T. (2011). The behavior of individual investors. In Handbook of the Economics of Finance, 2(B), 1533-1570.

Barrick, M. R., \& Mount, M. K. (1991). The Big Five personality dimensions and job performance: A meta-analysis. Personnel Psychology, 41(1), 25-41.

Bashir, T., Azam, N., Butt, A. A., Javed, A., \& Tanvir, A. (2013). Are behavioral biases influenced by demographic characteristics \& personality traits? Evidence from Pakistan. European Scientific Journal, 9(29), 277-293.

Bateman, H., Eckert, C., Geweke, J., Louviere, J., Thorp, S., \& Satchell, S. (2012). Financial competence and expectations formation: Evidence from Australia. Economic Record, 88(280), 39-63.

Belcher, L. J. (2010). Prior perceptions, personality characteristics and portfolio preferences among fund managers: An experimental analysis. Journal of Behavioral Finance, 11(4), 239- 248.

Bodnaruk, A., \& Simonov, A. (2015). Do financial experts make better investment decisions? Journal of Financial Intermediation, 24(4), 514-536.

Borden, L. M., Lee, E. S. A., Serido, E. L., Collins, E. D. (2008). Changing college students' financial knowledge, attitudes, and behavior through seminar participation, Journal of Family and Economic Issues, 29(1), 23-40. 
Borghans, L., Heckman, J. J., Golsteyn, B. H., \& Meijers, H. (2009). Gender differences in risk aversion and ambiguity aversion. Journal of the European Economic Association, 7(2-3), 649-658.

Breuer, W., Riesener, M., \& Salzmann, A. J. (2014). Risk aversion vs. individualism: what drives risk taking in household finance? The European Journal of Finance, 20(5), 446-462.

Brown, S., Garino, G., \& Taylor, K. (2013). Household debt and attitudes toward risk. Review of Income and Wealth, 59(2), 283-304.

Brown, S., \& Taylor, K. (2014). Household finances and the 'Big Five' personality traits. Journal of Economic Psychology, 45(Dec), 197-212.

Bucher-Koenen, T., \& Ziegelmeyer, M. (2011). Who lost the most? Financial literacy, cognitive abilities, and the financial crisis. ECB Working Paper No.1299.

Calcagno, R., \& Monticone, C. (2015). Financial literacy and the demand for financial advice. Journal of Banking E Finance, 50, 363-380.

Caliendo, M., Fossen, F., \& Kritikos, A. S. (2011). Personality characteristics and the decision to become and stay self-employed. Small Business Economics, 42(4), 787-814.

Cardak, B. A., \& Wilkins, R. (2009). The determinants of household risky asset holdings: Australian evidence on background risk and other factors. Journal of banking E Finance, 33(5), 850-860.

Christelis, D., Georgarakos, D., \& Haliassos, M. (2011). Stockholding: Participation, location, and spillovers. Journal of Banking $\mathcal{E}$ Finance, 35(8), 1918-1930.

Cobb-Clark, D. A., \& Schurer, S. (2012). The stability of big-five personality traits. Economics Letters, 115(1), 11-15.

Costa, P. T., \& McCrae, R. R. (1988). Personality in adulthood: A six-year longitudinal study of self-reports and spouse ratings on the NEO Personality Inventory. Journal of Personality and Social Psychology, 54(5), 853-863.

Disney, R., \& Gathergood, J. (2013). Financial literacy and consumer credit portfolios. Journal of Banking \& Finance, 37(7), 2246-2254. 
Dittrich, D. A., Guth, W., \& Maciejovsky, B. (2005). Overconfidence in investment decisions: An experimental approach. The European Journal of Finance, 11(6), 471-491.

Dohmen, T., Falk, A., Huffman, D., \& Sunde, U. (2010). Are risk aversion and impatience related to cognitive ability? American Economic Review, 100, 1238-1260.

Donnelly, G., Iyer, R., \& Howell, R. T. (2012). The Big Five personality traits, material values, and financial well-being of self-described money managers. Journal of Economic Psychology, 33(6), 1129-1142.

Dulebohn, J. H. (2002). An investigation of the determinants of investment risk behavior extroversion and sales performance. Journal of Applied Psychology, 81(6), 619.

Durand, R. B., Newby, R., \& Sanghani, J. (2008). An intimate portrait of the individual investor. The Journal of Behavioral Finance, 9(4), 193-208.

Durand, R., Newby, R., Tant, K., \& Trepongkaruna, S. (2013). Overconfidence, overreaction and personality. Review of Behavioral Finance, 5(2), 104-133.

Fenton-O'Creevy, M., Soane, E., \& Willman, P. (2001). Risk propensity and European Community. Journal of Applied Psychology, 82(1), 30.

Huston, S. J., (2010). Measuring Financial Literacy. The Journal of Consumer Affairs, 44(2), 296-316.

Filbeck, G., Hatfield, P., \& Horvath, P. (2005). Risk aversion and personality type. The Journal of Behavioral Finance, 6(4), 170-180.

Gaudecker, H., \& Von, M. (2015). How does household portfolio diversification vary with financial literacy and financial advice? The Journal of Finance, 70(2), 489-507.

George, J. M., \& Zhou, J. (2001). When openness to experience and conscientiousness are related to creative behavior: an interactional approach. Journal of Applied Psychology, 86(3), 513. 
George, J. M., \& Zhou, J. (2007). Dual tuning in a supportive context: Joint contributions of positive mood, negative mood, and supervisory behaviors to employee creativity. Academy of Management Journal, 50(3), 605-622.

Gosling, S. D., Rentfrow, P. J., \& Swann, W. B. (2003). A very brief measure of the Big-Five personality domains. Journal of Research in Personality, 37(6), 504-528.

Guiso, L., Sapienza, P., \& Zingales, L. (2008). Trusting the stock market. The Journal of Finance, 63(6), 2557-2600.

Hayes, A. F. (2012). PROCESS: A versatile computational tool for observed variable mediation, moderation, and conditional process modeling [White paper]. Retrieved from http://www.afhayes.com/public/process2012.pdf

Hilgert, M. A., Hogarth, J. M., \& Beverly, S. G. (2003). Household financial management: The connection between knowledge and behavior. Fed. Res. Bull., 89, 309.

Jappelli, T., \& Padula, M. (2011). Investment in financial literacy and savings decisions (No. 272). CSEF Working Paper.

Jappelli, T., \& Padula, M. (2013). Investment in financial literacy and saving decisions. Journal of Banking E Finance, 37(8), 2779-2792.

Jung, C. G. (2015). Psychology of dementia praecox (Vol. 1294). Princeton University Press.

Judge, T. A., Locke, E. A., Durham, C. C., \& Kluger, A. N. (1998). Dispositional effects on job and life satisfaction: The role of core evaluations. Journal of Applied Psychology, 83(1), 17.

Kliger, D., \& Levy, O. (2010). Overconfident investors and probability misjudgments. The Journal of Socio-Economics, 39(1), 24-29.

Komarraju, M., Karau, S. J., Schmeck, R. R., \& Avdic, A. (2011). The Big Five personality traits, learning styles, and academic achievement. Personality and Individual Differences, 51(4), 472-477. 
Kuhnen, C. M., Samanez-Larkin, G. R., \& Knutson, B. (2011). Serotonin and risk taking: How do genes change financial choices. Unpublished manuscript, Kellogg Sch. Manag., Northwestern Univ.

Lauriola, M., \& Levin, I. P. (2001). Personality traits and risky decisionmaking in a controlled experimental task: An exploratory study. Personality and Individual Differences, 31(2), 215-226.

Lengua, L. J., Sandler, I. N., West, S. G., Wolchik, S. A., \& Curran, P. J. (1999). Emotionality and self-regulation, threat appraisal, and coping in children of divorce. Development and Psychopathology, 11(01), 15-37.

Li, S., \& Liu, C. J. (2008). Individual differences in a switch from risk averse personality. London Business School, Centre for Organisational Research.

Liu, Y. H., \& Jiang, I. M. (2012). Influence of investor subjective judgments in preferences for gains to risk seeking preferences for losses: can personality variables predict the risk preferences? Journal of Risk Research, 11(5), 673-686.

Lusardi, A. (2008). Financial literacy: An essential tool for informed consumer choice? (No. w14084). National Bureau of Economic Research.

Lusardi, A., \& Mitchell, O. S. (2008). Planning and financial literacy: How do women fare (Working Paper No. 13750). National Bureau of Economic Research.

Lusardi, A., \& Mitchell, O. S. (2011). Financial literacy and retirement planning in the United States. Journal of Pension Economics and Finance, 10(04), 509-525.

Lusardi, Annamaria, and Olivia S. Mitchell. (2014). The economic importance of financial literacy: Theory and evidence. Journal of Economic Literature 52(1): 5-44.

Mayfield,C., Perdue, G \& Wooten, K. (2008). Investment management and personality type, Financial Services Review, 17(3), 219-236. 
Mendonca, M. R. (2016). Relating big five factor model to the acceptance and use of on-line shopping. International Journal of Marketing Studies, 8(3), 89-98.

Mitchell, O. S., \& Lusardi, A. (2015). Financial literacy and economic outcomes: Evidence and policy implications. The Journal of Retirement, 3(1), 107.

Mitteness, C., Sudek, R., \& Cardon, M. S. (2012). Angel investor characteristics that determine whether perceived passion leads to higher evaluations of funding potential. Journal of Business Venturing, 27(5), 592-606.

Muller, S., \& Weber, M. (2010). Financial Literacy and Mutual Fund Investments: Who Buys Actively Managed Funds? Schmalenbach Business Review, 62, 126-153.

Nga, J. K., \& Ken Yien, L. (2013). The influence of personality trait and demographics on financial decision making among Generation Y. Young Consumers, 14(3), 230-243.

Nicholson, N., Soane, E., Fenton-O'Creevy, M., \& Willman, P. (2005). Personality and domain-specific risk taking. Journal of Risk Research, 8(2), 157-176.

Nunnally, J. C., \& Bernstein, I. H. (1994). The assessment of reliability. Psychometric Theory, 3(1), 248-292.

Olsen, R. (2012). Trust: The underappreciated investment risk attribute. Journal of Behavioral Finance, 13(4), 308-313.

Riley Jr, W. B., \& Chow, K. V. (1992). Asset allocation and individual risk aversion personality and individual differences. Financial Analysts Journal, 48(6), 32-37.

Salgado, J. F. (1997). The five factor model of personality and job performance in the European Community. Journal of Applied Psychology, 82(1), 30-43.

Sadi, R., Asl, H. G., Rostami, M. R., Gholipour, A., \& Gholipour, F. (2011). Behavioral finance: The explanation of investors' personality and perceptual biases effects on financial decisions. International Journal of Economics and Finance, 3(5), 234. 
Schagen, S., \& Lines, A. (1996). Financial literacy in adult life: a report to the Natwest Group Charitable Trust (pp. 36-45). NFER.

Scollon, C. N., \& Diener, E. (2006). Love, work, and changes in extroversion and neuroticism over time. Journal of Personality and Social Psychology, 91(6), 1152.

Stewart, G. L. (1996). Reward structure as a moderator of the relationship between trading experience? Journal of Financial Markets, 12(2), 317-336.

Tsui, A. S., Nifadkar, S. S., \& Ou, Y. A. 2007. Cross-national, cross-cultural organizational behavior research: Advances, gaps, and recommendations. Journal of Management, 33(3), 426-478.

Van Rooij, M., Lusardi, A., \& Alessie, R. (2011). Financial literacy and stock market participation. Journal of Financial Economics, 101(2), 449-472.

Virlics, A. (2013). Investment decision making and risk. Procedia Economics and Finance, 6, 169-177.

Wang, A. (2009). Interplay of investors' financial knowledge and risk taking. The Journal of Behavioral Finance, 10, 204-213.

Wasiuzzaman, S., \& Edalat, S. (2016). Personality, risk tolerance and social network use: An exploratory study. Managerial Finance, 42(6), 536-552.

Xiao, Z., Wang, D., \& Liu, Y. (2009). Economic environment and personality: How do they influence investment decisions and regret? Social Behavior and Personality: An International Journal, 37(10), 1297-1304.

Yoong, J. (2010). Financial illiteracy and stock market participation: Evidence from the RAND American Life Panel. Financial literacy: Implications for retirement security and the financial marketplace, 76.

Zeigler-Hill, V., Besser, A., Vrabel, J., \& Noser, A. E. (2015). Would you like fries with that? The roles of servers' personality traits and job performance in the tipping behavior of customers. Journal of Research in Personality, 57(Aug), 110-118. 
Zhao, H., \& Seibert, S. E. (2006). The big five personality dimensions and entrepreneurial status: A meta-analytical review. Journal of Applied Psychology, 91(2), 259-271.

Zuckerman, M., \& Kuhlman, D. M. (2000). Personality and risk taking: common bisocial factors. Journal of Personality, 68(6), 999-1029. 